\title{
A Survey Report on the Improvement of Pragmatic Competence Under the Circumstances of Smart Learning Environment
}

\author{
Xiuxian Mo, Lixiang Lu, Fangting Liu, Yuwei Qin, Lanlan Liu, Lu Wen* \\ College of Foreign Studies, Guilin University of Electronic Technology, Guilin, Guangxi 541004, China \\ "Corresponding author. Email:10810489@qq.com
}

\begin{abstract}
This study adopts the method of questionnaire to research the improvement of college students' English pragmatic competence on the effect of online course learning platforms and APPs and so on. The results show that college students are more inclined to use APPs for English learning, and their English pragmatic competence has been significantly improved after using them, but the roles of online course platforms has been ignored in the learning process to some extent. Therefore, this study puts forward the suggestions from the aspects of the combination of course learning online platforms and APPs, highlighting the usage of hardware resources and English learning strategies.

Keywords: Pragmatic ability, smart learning, APPs, online course platforms, learning strategies
\end{abstract}

\section{INTRODUCTION}

According to the College English Curriculum Requirements in 2020, "The goal of college English teaching is to cultivate students' ability to apply English", "while developing autonomous learning ability" and "enabling students to use English properly and effectively in study and life as well as the future work". The application of technology in the field of education contributes to the construction of smart learning environment based on the application of information technology [1]. One of the characteristics of smart learning environment is that it is learner-centered, which supports learners' independent construction of learning and provides timely learning guidance [2], thus providing favorable conditions for English learning. Leech (1983) divided pragmatic competence into pragmatic-linguistic competence and society-pragmatic competence [3]. The former is based on grammatical competence and involves the use of rules of language. It not only refers to the ability of correctly using grammatical rules to construct sentences, but also includes the ability to use proper language forms in a certain context for applying a certain communicative function. As a higher level of pragmatic competence, social pragmatic competence refers to the ability to conduct appropriate communication in accordance with the social rules of language use.

Smart learning environment provides chances for the effective learning and application of English. However, due to the influence of many aspects, students' pragmatic competence in the intelligent learning environment varies. Therefore, this paper investigates on the current effect of intelligent learning environment on the improvement of college students' English pragmatic ability, while trying to give suggestions and strategies that may help college English teachers instruct students to use smart learning environment and improve their English pragmatic competence.

\section{SURVEY DESIGN}

\subsection{Research Questions}

This study attempts to answer the following questions: How do college students use online course learning platforms, English learning APPs and English learning strategies in smart learning environment? What suggestions and strategies should be put forward for the above situation so as to improve college students' English pragmatic competence?

A total of 46 questions are designed in this questionnaire, which is composed of five parts: The first part includes personal information of learners (gender, major, grade, city, etc.); The second part is the self-assessment of English pragmatic competence of learners, which includes the self-assessment of pragmatic competence items at levels 5 to 7 in the self-evaluation scale of pragmatic competence in China Standards of English. The third part is about students' status in using online course learning platforms and APPs when learning English. The fourth part is the investigation of learning physical equipment resources owned by learners, such as the use of smart classrooms, multimedia classrooms, e-learning resources (e-textbooks, e-notes, terminal learning equipment), etc. The fifth part is about learning strategies in intelligent learning environment, including memory strategies, cognitive strategies, compensation strategies and learning 
strategies that indirectly affect learning: metacognitive strategies, emotional strategies and social strategies.

The questions in the questionnaire were used to test the relationship between the frequency of using online course learning platforms, APPs and learning strategies and the improvement of college students' English pragmatic competence. The specific approach is to divide each section into a number of questions. In sections 2, section4 and section5, the answers to each question are set to "never, rarely, sometimes, often and always". In order to facilitate the statistics and analysis of data, the corresponding numerical value of answer options were set as "1, 2, 3, 4, 5" according to the Likert Scale, so that the average value of all questions in each module reflected the situation of that module.

\subsection{Analysis and collection of data}

In this survey, 267 questionnaires were distributed and all were recovered in the form of online questionnaires, with a recovery rate of $100 \%$. In this study, the online platform "WJX.com" was used for the compilation, distribution and data collection of questionnaires, and the convenient sampling method was adopted to carry out the survey. It took 10 days from the time when the questionnaire was officially distributed to the time when the questionnaire was stopped to be collected. The respondents are mainly from Guilin University of Electronic Technology, Guangxi Normal University and Guilin Institute of Aerospace Industry, including freshmen to seniors, which are representative to some extent. The following table shows the composition of the respondents.

Table 1 The information of respondents

\begin{tabular}{|c|c|c|}
\hline Respondents & NO. & Ratio \\
\hline Male & 137 & $51.31 \%$ \\
\hline Female & 130 & $48.69 \%$ \\
\hline Freshman & 81 & $30.34 \%$ \\
\hline
\end{tabular}

Table 3 Students' application of software resources

\begin{tabular}{|c|c|c|}
\hline \multicolumn{2}{|c|}{ Table 1, cont } \\
\hline Sophomore & 79 & $29.59 \%$ \\
\hline Junior & 96 & $35.96 \%$ \\
\hline Senior & 11 & $4.12 \%$ \\
\hline English major & 27 & $10.11 \%$ \\
\hline Non-English major & 240 & $89.89 \%$ \\
\hline Total & 267 & $100 \%$ \\
\hline
\end{tabular}

This questionnaire is designed based on the China Standards of English (CSE) released in 2018 and the Strategy Inventory for Language Learning (SILL) issued by Oxford (1990), and is revised according to the characteristics of the smart Learning environment. The results of the questionnaire were analyzed by using the online platform "WJX.com and SPSS software. Cronbach's Alpha coefficient (Cronbach coefficient: 0.945>0.9) was used to test the internal consistency. Good internal consistency was achieved and good reliability of the questionnaire was maintained.

Table 2 Result of KMO and Bartlett test

\begin{tabular}{|c|c|c|}
\hline \multicolumn{3}{|c|}{ KMO and Bartlett test } \\
\hline \multicolumn{2}{|c|}{ KMO value } & 0.927 \\
\hline \multirow{3}{*}{$\begin{array}{c}\text { Bartlett test for } \\
\text { sphericity }\end{array}$} & $\begin{array}{c}\text { Approximate Chi- } \\
\text { Square }\end{array}$ & 1914.55 \\
\cline { 2 - 3 } & df & 45 \\
\cline { 2 - 3 } & P value & 0 \\
\hline
\end{tabular}

\section{FINDINGS AND DISCUSSION}

\subsection{Software Resources}

\begin{tabular}{|c|c|c|c|c|c|c|}
\hline Ratio & Listening & Speaking & Reading & Writing & Translating & Vocabulary \\
\hline $\begin{array}{c}\text { Online } \\
\text { platforms }\end{array}$ & $33.33 \%$ & $41.57 \%$ & $28.09 \%$ & $37.22 \%$ & $16.48 \%$ & $25.84 \%$ \\
\hline APPs & $56.55 \%$ & $45.69 \%$ & $37.83 \%$ & $37.08 \%$ & $36.03 \%$ & $66.67 \%$ \\
\hline Others & $10.12 \%$ & $12.74 \%$ & $\begin{array}{c}28.46 \%( \\
\text { Printed } \\
\text { books })\end{array}$ & $\begin{array}{c}\text { Assignments and } \\
\text { face-to-face } \\
\text { communication) }\end{array}$ & $7.49 \%$ \\
\hline
\end{tabular}


As can be seen from Table 3, in the learning process of listening, speaking, reading, writing, translating and learning vocabulary, a large proportion of people use online course learning platforms and APPs. In terms of online course learning platforms, the average proportion of all aspects of English learning is about $28.08 \%$, among which the oral English learning one is the largest, while the proportion of translation learning is the smallest. In terms of APPs, the whole proportion of $53.81 \%$ is significantly increased, among which the number of students who use APPs for translation accounts for about $4 / 5$ of the study sample. More than $1 / 2$ of students use APPs for practicing listening and vocabulary, while a few of students use APPs to assist writing practice. However, in general, in the above table the proportion of people using APPs is higher than that of using online course platforms. Except for usage proportion of oral English learning, the gap between APPs and online course learning platforms is large, with the minimum difference being $9.74 \%$ and the maximum difference being $62.55 \%$. In addition, in the questionnaire, it is also found that $28.46 \%$ of the students use paper books in English or EnglishChinese for reading training. The proportion of students who are available to teachers' assignments and correction or face-to-face communication as the main way of writing training is $36.33 \%$, which is higher than the number of students who use the course online learning platform for the same target.

According to the above data, to a certain extent, APPs are more popular among college students than online course learning platforms. Both of them have the characteristics of convenient mobile learning, openness, interactivity, improving students' subjectivity[4], and improving college students' ability in English application. In terms of online course learning platforms, taking MOOC in China as an example, there are many excellent teachers, courses covering a wide range of aspects and the integrated course structure. However, for all aspects of English learning, it belongs to online video learning to a large extent as a single learning form. Compared to online learning platforms, APPs are better in diversity forms, and strong practicality. For example, some APPs help correct specific pronunciation errors from students' oral English, provide services of recording finished assignments, supervising and urging students to keep on learning, modifying the writing instantly. In addition, some APPs carry out the vocabulary competition to test the students' vocabulary. In the term of English translation APPs also provide great convenience for the students, for example, the current relatively popular APP Youdao Dictionary, with accurate content and rapidly translating, records the words and phrases from New Oxford English-Chinese Dictionary, Merriam-Webster's Collegiate Dictionary and other kinds of authoritative dictionaries. Learners can enjoy the services of the word translation, translation in photos and document, with other relevant lexical phrases for reference. In this study sample, a large amount of students still use traditional methods in reading and writing exercises, which demonstrates to some extent that no matter online course learning platforms or APPs, it is still difficult for them to replace traditional methods in English learning.

\subsection{Hardware Resources}

Table 4 Students' application of hardware resources

\begin{tabular}{|c|c|c|}
\hline NO. & Applications of hardware resource & Mean \\
\hline 18 & $\begin{array}{c}\text { Your English lessons will be taught in a } \\
\text { multimedia classroom (traditional tables } \\
\text { and chairs, projectors, computers, general } \\
\text { control systems). }\end{array}$ & 3.88 \\
\hline 21 & $\begin{array}{l}\text { You use smart devices like computers, } \\
\text { tablets and phones to learn English. }\end{array}$ & 3.63 \\
\hline 20 & $\begin{array}{c}\text { The level of e-learning resources you have, } \\
\text { including teaching materials, learning } \\
\text { extensions, etc. }\end{array}$ & 3.62 \\
\hline 17 & $\begin{array}{l}\text { Your English courses will be taught in the } \\
\text { smart classroom (desks and chairs with } \\
\text { group discussion function, touch projector } \\
\text { all-in-one machine with built-in electronic } \\
\text { whiteboard function, power amplifier, } \\
\text { speaker supporting teaching system, LED } \\
\text { display system, video monitoring system). }\end{array}$ & 3.26 \\
\hline 22 & $\begin{array}{l}\text { You use electronic notes for class notes, } \\
\text { problem sets, corrections, etc., and review } \\
\text { with the aid of electronic notes. }\end{array}$ & 2.83 \\
\hline 19 & $\begin{array}{c}\text { Your English lessons are taught in a } \\
\text { traditional classroom without electronic } \\
\text { equipment. }\end{array}$ & 2.14 \\
\hline 23 & You interact with the AI robot in English. & 1.99 \\
\hline 24 & $\begin{array}{c}\text { You use VR and kinect devices to immerse } \\
\text { yourself in an English environment. }\end{array}$ & 1.82 \\
\hline
\end{tabular}

Table 4 lists the use of hardware resources such as English teaching classroom, e-learning resources, electronic intelligent devices and high-tech products in the smart learning environment. The first three questions are about the use of classrooms for English course learning. The mean value of question 17 is 3.26 , that of question 18 is 3.88 , and that of question 19 is 2.14 . By comparing the three questions, we find that many colleges and universities still lack smart information technology equipment. Or the teachers' ability to use information technology is relatively low, which makes it difficult for all kinds of modern information technology to be effectively applied in English teaching. It reflects that the physical environment of perceptual learning, the learning place, has changed under the smart learning environment. 
From the original traditional classroom without any electronic devices to the multimedia classrooms with general technology, the classrooms used for English learning have developed into the smart classroom with interactive, perceptive, open and easy-to-use Internet of technology. More and more abundant hardware resources are available in English learning classes, which can better meet students' needs for acquiring knowledge, stimulate students' learning motivation and exploration spirit, and improve college students' pragmatic English ability.

In question 20 , the mean value is 3.62 , ranking the third, indicating that under the smart learning environment, college students have abundant e-learning resources,

Table 5 Students' micro strategies of English learning including e-textbooks and learning materials. The mean values of 21 and 22 are 3.63 and 2.83 , indicating that it is more and more common for college students to use computers, tablets and other electronic intelligent devices to learn English. Questions 23 and 24 are about high-tech products. The mean value is lower. This indicates that under the smart learning environment, students have not fully utilized high-tech products such as VR, Kinect devices and AI robots to learn English, and their awareness of immersive English learning is low.

\subsection{Strategies of English Learning}

\begin{tabular}{|c|c|c|}
\hline No. & The micro strategies & Mean \\
\hline 38 & $\begin{array}{r}\text { When I feel tired from studying online, I will find many ways to relax myself, such as playing } \\
\text { games, listening to music and so on. }\end{array}$ & 3.63 \\
\hline 32 & $\begin{array}{r}\text { When using some learning software, I am very willing to accept the software to make the } \\
\text { corresponding learning plan according to my learning situation. }\end{array}$ & 3.2 \\
\hline 31 & $\begin{array}{r}\text { When using learning software, I can have a greater sense of achievement through intuitive } \\
\text { learning data, and I will be more active in learning. }\end{array}$ & 3.17 \\
\hline 37 & $\begin{array}{r}\text { In the free online learning time, you can plan your time properly without any interference } \\
\text { from other Internet content. }\end{array}$ & 2.03 \\
\hline 35 & $\begin{array}{c}\text { I think about the connection between what I have learned in English on the Internet and what } \\
\text { I already know. }\end{array}$ & 2.87 \\
\hline 36 & $\begin{array}{c}\text { Compared to traditional teaching, you think you are more interactive in online learning. } \\
\text { I often make material summaries after learning online courses, such as writing English } \\
\text { listening, English grammar and reading reports. }\end{array}$ & 2.79 \\
\hline 34 & $\begin{array}{c}\text { I will visit overseas course websites such as Harvard University and MIT, so that I can not } \\
\text { only learn English, but also master the course contents of foreign famous universities. }\end{array}$ & 2.35 \\
\hline
\end{tabular}

Table 5 lists the frequency of using micro strategies in English learning from high to low in the case of intelligent learning. As can be seen from the above table, among the top three micro-learning strategies with the highest frequency of use, one belongs to emotional strategy and the other two belong to cognitive strategy. The highest mean value is 38 , indicating that under the intelligent learning environment, students generally use emotional strategies for assistance, and can better perceive their mental state and physical state in learning, actively reflect on themselves, and adapt to the constantly changing learning content. Questions 31 and 32 titled cognitive strategies that wisdom learning environment for students' English study provides data support formulates personalized learning solutions to reach the effect according to their aptitude. Students can arouse their learning motivation by intuitive learning data, which timely records students' learning process and learning behavior so that students can domain their study, positively accept knowledge relying on the smart study environment.

In the bottom five less frequently used questions, two were metacognitive strategies and three were cognitive strategies. The minimum is Question 34, suggesting that the frequency of foreign courses is low, while the utilization of English movies, songs, teaching classes, and other network learning resources is high. This is related to the students' English foundation, the support of the network technology environment, and other factors. College students cannot identify English learning resources and are prone to indulge in some virtual websites irrelevant to learning. They pay little attention to the valuable resources that are helpful for English learning, and the effective utilization rate of resources is low. In Question 37, students can plan their time properly and not be disturbed by other Internet content. The low mean value indicates that college students generally lack selfmonitoring ability, low metacognitive ability, and poor 
self-learning effect. Therefore, effective supervision and guidance from teachers are needed to reasonably manage and supervise the learning process.

\subsection{Self-assessing of Pragmatic Competence}

Table 6 Results of self-assessing of students' pragmatic competence

\begin{tabular}{|c|c|c|}
\hline NO. & Questions according to CSE & Mean \\
\hline 15 & $\begin{array}{l}\text { I can express my thanks and condolences in } \\
\text { a formal setting. }\end{array}$ & 3.1 \\
\hline 7 & $\begin{array}{l}\text { I can understand and express Thanks } \\
\text { appropriately in more formal situations, } \\
\text { such as "Thanks go first to...". }\end{array}$ & 3.07 \\
\hline 10 & $\begin{array}{l}\text { I can understand formal compliments and } \\
\text { respond reasonably, such as "Your topic is } \\
\text { very interesting." or "Thank you. I am glad } \\
\text { you like it, but...". }\end{array}$ & 2.94 \\
\hline 9 & $\begin{array}{l}\text { I can choose appropriate words according to } \\
\text { different social situations to achieve } \\
\text { communicative purposes. }\end{array}$ & 2.89 \\
\hline 14 & $\begin{array}{l}\text { I can distinguish the small difference of } \\
\text { ways of persuasion, such as "No smoking" } \\
\text { and "It would be nice if you could..." }\end{array}$ & 2.87 \\
\hline 6 & $\begin{array}{l}\text { I can understand and express regret in } \\
\text { different social situations, such as "I wish I } \\
\text { could go back and start all over again." }\end{array}$ & 2.86 \\
\hline 8 & $\begin{array}{l}\text { I can interrupt negotiations in more formal } \\
\text { settings with simple terms, such as "Could I } \\
\text { interrupt you for a minute?" }\end{array}$ & 2.8 \\
\hline 11 & $\begin{array}{c}\text { I can understand and tactfully express } \\
\text { skepticism in formal situations, such as } \\
\text { "Your performance would have been better } \\
\text { if you had done...". }\end{array}$ & 2.74 \\
\hline 13 & $\begin{array}{c}\text { I can understand and effectively explain the } \\
\text { verbal conflicts caused by cultural } \\
\text { differences. }\end{array}$ & 2.74 \\
\hline 12 & $\begin{array}{l}\text { I can choose appropriate language for } \\
\text { communication according to the cultural } \\
\text { background of the communication partner. }\end{array}$ & 2.67 \\
\hline
\end{tabular}

KMO and Bartlett tests have been used to verify the validity of this self-assessment. It can be seen from the above table that the KMO value is 0.927 and the KMO value is greater than 0.8 , indicating that the validity of the research data is reasonable. The reliability of data research has been mentioned above, so it will not be repeated here.

The average score of the ten questions is about 2-3 points, which indicates that students' assessment of their English pragmatic level is generally moderate under different smart learning environments, which to some extent reflects students' low level of effective use of English under different situations. In Question 15, the average score is the highest, which indicates that college students are better at pragmatic behaviors related to gratitude and consolation. In Question 12, the average score is the lowest, indicating that students' expression will be affected in pragmatic communication due to the different cultural backgrounds of the communicative parties. The average scores of various pragmatic competence tests are not different, which indicates that students' pragmatic competence can get more balanced development under different smart learning environments. We can also see that under different smart learning environments, there is a significant difference in the proportion of students using online course platforms and APPs. According to the above data, to a certain extent, APPs are more popular among college students than online course learning platforms. Both of them have the characteristics of mobile learning, such as convenience, openness, interactivity, change, and improve students' subjectivity, and improve college students' ability in English application. In such a convenient, effective learning environment, students using of online learning platform account for the minority, while the number of people using APPs are in majority. Besides, students have different learning strategies, which, to some extent, indicates that students' learning through APPs is more effective in improving their pragmatic competence and is more popular.

According to the data analysis, students' self-assessment scores of pragmatic competence are generally low, which is generally caused by two aspects: language errors and social pragmatic failures. Communication subjects with different cultural backgrounds, due to their national characters, values, and ways of thinking, will naturally have collisions and conflicts in cross-cultural communication. To reduce conflicts, it is necessary to improve language communication ability while mastering language knowledge [5]. For example, Question 7 is a more formal way of speaking. If we use it in our daily conversation, we tend to use "thanks" or "thank you". In different situations, the language used should be different. In daily communication, oral language should be used instead of written language. To effectively improve English pragmatic competence, it is necessary to make full use of English smart online learning platforms and various APPs in the current environment of smart learning. 


\subsection{Comparison of Students' Scores}

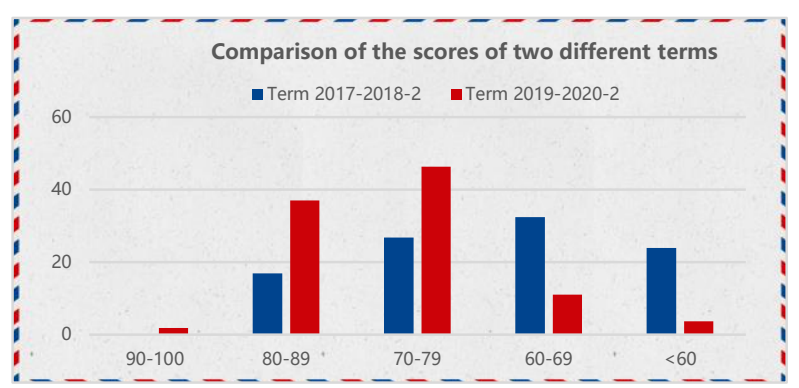

Figure 1 Comparison of the scores of College English between two semesters

The figure above is the comparison of the final assessment scores for the same teaching content in different teaching periods from two non-English major classes of Guilin University of Electronic Technology. The assessment scores were gained in the Term of 2017-2018-2 and the Term of 2019-2020-2 respectively. It can be seen from the figure that only $16.90 \%$ of the students' assessment scores in the previous semester were in the $80-89$ section, and $26.79 \%$ of the students scored in the 70-79 section. About two-fifths of the students scored more than 70, and the passing rate was $76.056 \%$. In the latter semester, $37.04 \%$ of the students scored $80-89,46.30 \%$ of the students scored 70-79, and more than $4 / 5$ of the students scored over 70 . The passing rate reached $96.296 \%$, much higher than that in the former semester.

It can be inferred from the above data that the latter is more effective in improving English learning than the former, and students in the latter have a higher comprehensive English ability than that in the former, such as listening, speaking, reading, writing and translation skills, critical thinking ability, cross-cultural communication ability, language understanding ability, language expression ability, language knowledge and so on. In the semester 2017-2018-2, students receive traditional English education in offline classes. In the second semester of 2019-2020-2, due to the influence of COVID-2019, teachers adopted an online and offline blended teaching mode. In such a mode, it is helpful to encourage students who have few offline classroom speeches to participate more actively in classroom discussions online, and easier for teachers and students to have a positive interaction. Meanwhile, teachers can collect the students' answers through the Internet and make timely teaching adjustments based on the students' situation. It is learned from the questionnaire that students tend to use APPs to English autonomous learning. For example, they can guess the meanings of words through the picture and repeat the same words learning with the help of APP Baicizhan as well as enjoy the services of instant translation and providing references in Baidu translation. Also students can use the comprehensive functions in reading and listening practice, with various materials in APP Daily English Listening. These APPs provide more opportunities for students to immerse themselves into the native culture of English-speaking countries so as to arouse their enthusiasm in English learning.

\section{SUGGESTIONS AND INSPIRATIONS}

According to the above analysis, it can be seen that there is a big gap between the number of students using the online course learning platforms and APPs in the three universities in Guilin, and the smart learning resources available around them are not so effectively beneficial as expected. There are also some problems in micro strategies of English learning, which have different influences on the improvement of college students' English pragmatic ability. The following are the relevant suggestions based on the above data analysis:

\subsection{The Combination of Online Platforms and APPs}

Although APPs have rich variety and practicality is strong, they are not systematical and too fragmented, easily leading students to absorb one-sided content. This may play a negative role in the promotion of students' English pragmatic competence. And course online learning platforms can make up for this deficiency. Therefore, we believe that college English teachers should guide students to correctly understand the advantages and disadvantages of online course learning platforms and APPs, and combine the two to make full use of their merits and avoid their shortcomings. For example, when college students have a listening course, they can use APPs to help them understand the teaching content when it is difficult to understand the teaching content.

\subsection{The Enhancement of the Application of Hardware Resources}

Although most college English courses are taught in smart classrooms, some schools still remain the traditional or multimedia classrooms. Colleges and universities should make full use of hardware resources, accelerate the construction and use of smart classrooms, and make use of modern information technology to create an optimal environment for English learning.

\subsection{Stimulating the Motivation of College Students' Independent English Learning}

Many college students have the awareness of English learning, but due to the influence of many factors, they lack goals of English learning. A smart learning environment makes college students' learning more flexible. But only if college students have a clear goal of Learning English can they study efficiently. According to 
their interests and time, students can timely access to relevant learning resources, take the initiative to arrange English self-study, collaborative learning, and distance learning. For example, by reading English articles and watching English movies online or taking online courses, you can arrange learning activities anytime and anywhere. In the later stage of learning, college students can record and feedback the learning behavior information provided by the software. By referring to the learning data provided by the learning APPs, students can take the initiative to monitor and evaluate their learning process and constantly adjust their English learning goals. Therefore, college students should fully understand their learning style and take the initiative to adopt effective learning methods to achieve personalized learning of English.

\subsection{Improvement of Students' Metacognitive Ability and Self-management Ability}

Metacognition refers to "cognition of cognition", including the regulation and control of cognitive behavior by knowledge and concepts of a cognitive process [6]. To improve their independent English learning ability, college students should first have a comprehensive and objective understanding of English learning, and customize their learning plan with the help of excellent resources in the intelligent learning environment. According to the learning process records and data analysis, I actively manage and monitor my behavior in English learning, and conduct selfevaluation and reflection on the learning results, to continuously improve myself and improve my selfmanagement ability and form effective metacognitive strategies.

\section{CONCLUSION}

This study also has some shortcomings. For example, the number of samples collected in the questionnaire is too small to represent the actual situation of all university students in Guangxi. Through this questionnaire, we know that college students who use APPs account for a larger proportion. We can only know that APPs help improve college students' English pragmatic ability, but we cannot investigate the specific help of online course learning platform for improving their English pragmatic ability. The questions of the questionnaire on English pragmatic competence are subjective and the accuracy of the survey is not high. Finally, we will further discuss these problems in future research.

\section{ACKNOWLEDGMENT}

(1) This work is supported by the Training Program of Innovation and Entrepreneurship for Undergraduates of Guangxi in 2019 (201910595244).

(2) This work is supported by the Planning Project of Guangxi Education Sciences: "Research on the Long-term Mechanism and Implementation Path of Guangxi Minority Culture Inheritance Education through Cooperation between University and Secondary Vocational School" (Grant No. 2019ZJY111).

\section{REFERENCES}

[1] Chin, K. W. (1997). Smart learning environment model For secondary schools in Malaysia: An overview [EB/OL]. http://www, apdip, net/projects/seminars/itpolicy/cn/ resources/kangwaichin/smartleaming-mimos. ppt.

[2] Zhong Guoxiang, Zhang Xiaozhen, A Building of the Current Intelligent Learning Environment Model. Computer Science. 2007, Vol. 34. No. 1, 170-171+197.

[3] Leech, GN. Principles of Pragmatics. 1983. London: Longman.

[4] Liu Yanxia, Liu Xinxia. A Study on the Application Possibility of MOOC in Undergraduate English Teaching. Knowledge Economy. 2019, Vol. $21,124+126$.

[5] Han Donghong, Lan Yuming, Yao Wenqing. An Investigation and Analysis of the Pragmatic Competence of students majoring in Foreign affairs. Journal of Xi' an International Studies University. Vol. 10, No. 4, 2002. 79-82.

[6] Wei Na, Zhao Yuling. The Cultivation Strategies of College Students' English Autonomous Learning Ability under the environment of intelligent Learning. The Chinese Journal of ICT in Education. 2017, Vol. 16, 70-73. 